\title{
Membangun Wilayah Perbatasan Di Provinsi Kepulauan Riau \\ (Mencari Solusi Untuk Peningkatan Kesejahteraan Masyarakat Di Pulau-Pulau Terdepan)
}

\author{
Agus Hendrayady \\ Dosen Ilmu Administrasi Negara \\ Fakultas Ilmu Sosial dan IImu Politik \\ Universitas Maritim Raja Ali Haji \\ agushendrayady5873@umrah.ac.id
}

\begin{abstract}
In the Riau Islands Province which is a problem in the border region, among others, is the very wide stretch of border areas, still lack of management of potential and natural resources both state and private, handling border areas that have not been maximized and are still partial or sectoral, education and welfare levels which is still low compared to people in neighboring countries such as Singapore and Malaysia, the lack of security and defense facilities and infrastructure which can lead to weak supervision of violations of state borders, and the lack of integration of programs and activities in border area development. The formulation of the problem in this study is: How are the efforts to Build a Border Area in the Riau Islands Province in order to find a solution to improve community welfare on the front islands. The aim of the study was to find out how the government's efforts in Building Border Areas in the Riau Islands Province in order to improve Community Welfare on the Leading Islands. This study uses library research methods, namely by using secondary data from sources that are used as objects of research, both books or literature, electronic media (internet sites), online media, which have to do with the problem of this research. Data collection in this study was conducted using library studies. The efforts made by the Riau Islands Provincial Government to find solutions to improve the welfare of the people on the leading islands are the Launching of the Integrated Border Area Movement Development Program (Gerbangdutas) in Natuna Regency, Accelerating rehabilitation of habitable homes, markets, schools, health centers, Village and Village Development Acceleration Program (P3DK), efforts to resolve national borders, and increase electrification, especially in small islands and remote areas through the construction of solar power plants, micro hydro power plants and power plant technology development Electric Power and construction of ports / piers in the border area. On the other hand, because of the strategic nature of the Riau Islands Province, it needs to be supported by good connectivity, especially sea connectivity. Therefore, a number of ports and ferry boats are built which are a priority so as to reduce intra-regional and inter-regional disparities. Batam as a city that also borders directly with neighboring Singapore is used as an industrial, tourism, shipping and service area. Another form carried out in the context of building border areas is by implementing the Sea Toll Program. It is expected that with the relationship between sea ports, there will be smooth delivery of goods to border areas. The Sea Toll Program is carried out, especially for the Riau Islands Province because the Riau Islands region has many seas. Whereas in the field of
\end{abstract}


infrastructure, especially related to infrastructure, the Provincial Government of Riau Islands and PT. PLN in Riau Region and Riau Islands faces many obstacles, especially for border areas with many disruptions and constraints, especially because the condition of the Riau Islands is the sea, in addition to weather and climate factors which are often uncertain and the absence of port loading and unloading facilities.

\title{
Keywords: Development, Border, Community Welfare.
}

\begin{abstract}
ABSTRAK
Di Provinsi Kepulauan Riau yang menjadi permasalahan di wilayah perbatasan antara lain adalah sangat luasnya bentangan kawasan perbatasan, masih kurangnya pengelolaan potensi dan sumber daya alam baik oleh negara maupun swasta, penanganan daerah perbatasan yang belum maksimal dan masih bersifat parsial ataupun sektoral, tingkat pendidikan dan kesejahteraan yang masih rendah jika dibandingkan dengan masyarakat yang berada di negara tetangga seperti Singapura dan Malaysia, masih minimnya sarana dan prasarana keamanan dan pertahanan yang dapat menyebabkan lemahnya pengawasan terhadap pelanggaran batas wilayah negara, dan belum adanya keterpaduan program dan kegiatan pengembangan kawasan perbatasan. Adapun rumusan masalah pada penelitian ini adalah : Bagaimana upaya Membangun Wilayah Perbatasan Di Provinsi Kepulauan Riau dalam rangka Mencari Solusi Untuk Peningkatan Kesejahteraan Masyarakat Di Pulau-Pulau Terdepan. Tujuan penelitian adalah untuk mengetahui bagaimana upaya pemerintah dalam Membangun Wilayah Perbatasan Di Provinsi Kepulauan Riau dalam rangka meningkatkan Kesejahteraan Masyarakat Di Pulau-Pulau Terdepan. Penelitian ini menggunakan metode riset kepustakaan, yaitu dengan menggunakan data-data sekunder dari sumber-sumber yang dijadikan objek penelitian, baik buku-buku atau literatur, media elektronik (situs internet), media online, yang ada kaitannya dengan masalah penelitian ini. Pengumpulan data dalam penelitian ini dilakukan dengan menggunakan studi kepustakaan. Upaya-upaya yang dilakukan oleh Pemerintah Provinsi Kepulauan Riau untuk mencari solusi dalam rangka peningkatan kesejahteraan masyarakat di pulau-pulau terdepan adalah Pencanangan Program Gerakan Pembangunan Terpadu Kawasan Perbatasan (Gerbangdutas) di Kabupaten Natuna, Percepatan rehabilitasi rumah layak
\end{abstract}


36 | Jurnal Agus Hendrayady. Membangun Perbatasan...

huni, pasar, sekolah, puskesmas, Program Percepatan Pembangunan Desa dan Kelurahan (P3DK), upaya penyelesaian batas negara, serta peningkatan elektrifitas terutama di pulau-pulau kecil dan daerah terpencil melalui Pembangunan Pembangkit Listrik Tenaga Surya (PLTS), Pembangkit Listrik Tenaga Mikro Hidro (PLTMH) serta Pengembangan Teknologi Pembangkit Listrik Tenaga Arus Listrik dan pembangunan pelabuhan/dermaga di wilayah perbatasan. Disisi lain, karena strategisnya wilayah Provinsi Kepulauan Riau ini maka perlu didukung dengan konktivitas yang baik terutama konektivitas laut. Oleh karena itu maka dibangun beberapa pelabuhan dan kapal penyeberangan yang menjadi prioritas sehingga dapat mengurangi kesenjangan intra wilayah dan antar wilayah. Batam sebagai sebuah kota yang juga berbatasan secara langsung dengan negara tetangga Singapura dijadikan daerah industri, pariwisata, perkapalan, dan jasa. Bentuk lain yang dilakukan dalam rangka membangun wilayah perbatasan adalah dengan melaksanakan Program Tol Laut. Diharapkan dengan adanya hubungan antar pelabuhan-pelabuhan laut, maka akan tercipta kelancaran pengiriman barang hingga daerah-daerah perbatasan. Program Tol Laut dilakukan, terutama untuk daerah Provinsi Kepulauan Riau adalah dikarenakan wilayah Kepulauan Riau banyak laut. Sedangkan dibidang infrastruktur, terutama terkait dengan bidang infrastruktur, maka Pemprov Kepri dan PT. PLN Wilayah Riau dan Kepulauan Riau menghadapi banyak kendala, terutama untuk daerah perbatasan yang banyak gangguan dan kendala, terutama karena kondisi Kepulauan Riau adalah lautan, disamping faktor cuaca dan iklim yang seringkali tidak menentu dan tidak adanya fasilitas bongkar muat pelabuhan.

\section{Kata Kunci : Pembangunan, Perbatasan, Kesejahteraan Masyarakat.}

\section{Pendahuluan}

Pembicaraan tentang membangun negera dimulai dari perbatasan, bukanlah wacana baru. Hal ini sudah sering dibicarakan sejak lama. Indonesia yang memiliki perbatasan darat dan perbatasan laut dengan 10 (sepuluh) negara. Kawasan perbatasan darat antara Republik Indonesia dengan Negara Malaysia di Kalimantan Barat dan Kalimantan Timur, Republik Indonesia dengan Negara Papua New Guinea di Papua, dan Perbatasan Republik Indonesia dengan Negara Timor Leste di Nusa Tenggara Timur. Sedangkan 
perbatasan laut, Republik Indonesia berbatasan dengan negara-negara India, Thailand, Singapura, Malaysia, Vietnam, Philipina, Australia. untuk Provinsi Kepulauan Riau dengan dikeluarkannya Peraturan Presiden Nomor 78 Tahun 2005 dikatakan bahwa sebanyak 20 titik dari 92 pulau terdepan Indonesia berada di Provinsi Kepulauan Riau. Adapun ke 20 pulau terdepan itu 4 (empat) titik di wilayah Kota Batam yang terdiri dari Pulau Batu Berhanti di Perairan Selat Singapura berbatasan dengan Singapura, Selanjutnya Pulau Nipah di Selat Singapura, Pulau Nongsa di Selat Singapura, Pulau Pelampong di Selat Singapura yang kesemuanya berbatasan dengan Negara Singapura. 2 (Dua) pulau di Kabupaten Karimun yang terdiri dari Pulau Iyu Kecil di Selat Malaka, berbatasan dengan Negara Malaysia, serta Pulau Karimun Kecil di Selat Malaka, yang juga berbatasan dengan Negara Malaysia. 1 (satu) pulau di Kabupaten Bintan yaitu Pulau Batu Mandi di Selat Malaka yang berbatasan dengan Negara Malaysia. Selain itu juga ada 13 (tiga belas) pulau di Kabupaten Natuna yakni Pulau Damar, Pulau Kepala, Pulau Sebetul, Pulau Sekatung, Pulau Semiun, Pulau Sentut, Pulau Senua, Pulau Subi Kecil, Pulau Tokong Belayar, Pulau Tokong Malang Biru, Pulau Tokong Nanas, Pulau Tokong Boro, dan Pulau Mangkai, yang memiliki perbatasan dengan Negara Malaysia, Singapura, dan Vietnam.

Salah satu rencana induk pengembangan wilayah perbatasan di Provinsi Kepulauan Riau adalah memacu peningkatan kesejahteraan dan memberdayakan masyarakat perbatasan yang sinergis dengan perekonomian wilayah negara tetangga dan wilayah lainnya. Sebagai salah satu provinsi di wilayah perbatasan, Pemerintah Provinsi Kepulauan Riau tentunya memiliki tugas berat terkait perlindungan dan pengembangan masyarakatnya yang berada di beranda depan negara Republik Indonesia ini. Hendrayady (2018:1), menyatakan bahwa wilayah yang perkembangannya cukup tertinggal pembangunannya dibandingkan wilayah lain di Indonesia adalah wilayah perbatasan. Wilayah perbatasan identik dengan daerah perdesaan, daerah pinggiran, daerah tertinggal, atau daerah miskin yang cenderung termaginalkan. Oleh karena itu, didalam Program Nawacita Jokowi - JK, pembangunan perbatasan ini termuat dalam poin ketiga, yaitu : "Membangun Indonesia dari Pinggiran".

Membangun wilayah perbatasan tidaklah mudah, hal ini dikarenakan perlunya pemahaman tentang karakteristik kawasan perbatasan itu sendiri. 
Menurut Luthfi (dalam Sari, 2014), Pembangunan kawasan perbatasan dapat dimulai dengan mengenali terlebih dahulu potensi dan masalah yang dilihat dari karakteristik serta tipologi kawasan perbatasan. Didalam kerangka umum pengembangan wilayah Provinsi Kepulauan Riau disebutkan bahwa arah pengembangan wilayah Provinsi Kepulauan Riau disusun dengan memperhatikan potensi, permasalahan dan isu strategis pada masing-masing wilayah sehingga dapat mengurangi kesenjangan antar wilayah, maupun antar kelompok pendapatan, semangat dan tekad kuat membangun daerah untuk meraih kemajuan, meningkatkan kemandirian, dan memperkuat daya saing daerah, sehingga mampu meningkatkan kesejahteraan masyarakat secara merata dan berkeadilan. (RPJMD Provinsi Kepulauan Riau Tahun 20162021:VI-24).

Di Provinsi Kepulauan Riau yang menjadi permasalahan di wilayah perbatasan antara lain adalah sangat luasnya bentangan kawasan perbatasan, masih kurangnya pengelolaan potensi dan sumber daya alam baik oleh negara maupun swasta, penanganan daerah perbatasan yang belum maksimal dan masih bersifat parsial ataupun sektoral, tingkat pendidikan dan kesejahteraan yang masih rendah jika dibandingkan dengan masyarakat yang berada di negara tetangga seperti Singapura dan Malaysia, masih minimnya sarana dan prasarana keamanan dan pertahanan yang dapat menyebabkan lemahnya pengawasan terhadap pelanggaran batas wilayah negara, dan belum adanya keterpaduan program dan kegiatan pengembangan kawasan perbatasan.

Gubernur Kepulauan Riau, Nurdin Basirun dalam Rakor Pengelolaan Wilayah Perbatasan tahun 2016 mengatakan, "Sejumlah daerah perbatasan di Provinsi Kepulauan Riau, sangat membutuhkan pembangunan saranaprasarana dalam kesejahteraan dan perekonomian masyarakat." (https://batamtoday.com/home/read/78242/Daerah-Perbatasan-Kepri-ButuhInfrastruktur-dan-Kesejahteraan). Oleh karena itu, koordinasi dan sinergitas pemerintah daerah dan pemerintah pusat dalam hal ini kementerian atau lembaga terkait sangat diharapkan dalam meningkatkan pembangunan infrastruktur dan kesejahteraan masyarakat dikawasan perbatasan Provinsi Kepulauan Riau. Dengan demikian menurut Nurdin Basirun lagi, "Pembangunan infrastruktur dan sarana - prasarana umum dalam meningkatkan ekonomi masyarakat di sejumlah pulau-pulau terdepan 
Kepulauan Riau sangat penting dan dibutuhkan dalam upaya peningkatan kesejahteraan masyarakat". "Jika tiap daerah aksesnya sudah baik maka pemerataan kesejahteraan ada di tiap-tiap pulau di Kepulauan Riau." (https://batamtoday.com/home/read/78242/Daerah-Perbatasan-Kepri-ButuhInfrastruktur-dan-Kesejahteraan).

Berdasarkan uraian pada latar belakang yang menunjukkan bahwa membangun wilayah perbatasan merupakan masalah yang krusial yang harus mendapatkan perhatian terutama oleh aparatur Pemerintah Provinsi Kepulauan Riau apalagi dalam upaya untuk meningkatkan kesejahteraan masyarakat. Demi kemudahan arah dalam penelitian maka penulis membatasi masalahnya yaitu Membangun Wilayah Perbatasan Di Provinsi Kepulauan Riau (Mencari Solusi Untuk Peningkatan Kesejahteraan Masyarakat Di Pulau-Pulau Terdepan).

Untuk mempermudah penelitian, maka dipandang perlu untuk penulis memberikan rumusan masalahnya, sehingga jelas arah dan tujuan pembahasan masalah penelitian tersebut. Adapun perumusan masalahnya adalah : Bagaimana upaya Membangun Wilayah Perbatasan Di Provinsi Kepulauan Riau dalam rangka Mencari Solusi Untuk Peningkatan Kesejahteraan Masyarakat Di Pulau-Pulau Terdepan.

Berdasarkan rumusan masalah tersebut, maka yang menjadi tujuan penelitian ini adalah untuk mengetahui bagaimana upaya pemerintah dalam Membangun Wilayah Perbatasan Di Provinsi Kepulauan Riau dalam rangka meningkatkan Kesejahteraan Masyarakat Di Pulau-Pulau Terdepan.

\section{Tinjauan Pustaka}

\section{A. Pembangunan}

Beragam pengertian yang diberikan diberikan oleh para ahli mengenai pembangunan, salah satunya sebagaimana yang disampaikan oleh Siagian (2005:4), "Suatu usaha atau rangkaian usaha pertumbuhan dan perubahan yang berencana dan dilakukan secara sadar oleh suatu bangsa, negara dan pemerintah menuju modernitas dalam rangka pembinaan bangsa (nation building)." Dari pendapat yang diberikan oleh Siagian ini jelas menunjukkan bahwa pembangunan merupakan bentuk dari pertumbuhan dan perubahan, dimana kedua hal ini dilakukan secara berencana dan sadar, yang artinya bahwa pembangunan harus dilakukan dengan perencanaan yang baik dan 
penuh dengan kesadaran tentang apa yang ingin dibuat, seperti pembangunan di daerah tapal batas darat Indonesia, yaitu membangun 7 (tujuh) Pos Lintas Batas Negara (PLBN) dengan harapan pembangunan kawasan perbatasan ini dapat menjadi etalase tentang pembangunan yang sedang dijalankan oleh pemerintah kepada negara tetangga. Disamping itu kawasan perbatasan ini juga menjadi titik pertumbuhan perekonomian baru, dan dengan sendirinya akan dapat meningkatkan kesejahteraan masyarakat.

Pengertian pembangunan yang disampaikan oleh Siagian tersebut juga menunjukkan bahwa pembangunan haruslah menuju modernitas, yang artinya bahwa pembangunan yang dilakukan itu harus mengikuti arus perkembangan modernisasi, namun satu hal yang harus diingat bahwa pembangunan tersebut tidak boleh meninggalkan jati diri bangsa dan negara.

B. Wilayah Perbatasan

Konsep perbatasan menurut Nurmandi, dkk (2012:34) telah dikenal sejak era lahirnya negara bangsa, tepatnya ketika ditandatanganinya Perjanjian Westphalia pada tanggal 24 Oktober 1648. Pengertian perbatasan sendiri menurut Riswanto Tirtosudarmo (dalam Nurmandi, dkk, 2012:36) adalah sebuah ruang geografis yang sejak semula merupakan wilayah perebutan kekuasaan antarnegara, terutama ditandai oleh adanya pertarungan untuk memperluas batas-batas antar negara.

Perbatasan pada dasarnya memiliki 5 bentuk, yaitu Perbatasan Darat, Perbatasan yang dibentuk oleh Sungai, Perbatasan berbentuk Pegunungan, Perbatasan Laut, dan Perbatasan Udara. Perbatasan darat adalah tempat kedudukan titik-titik atau garis-garis batas yang memisahkan daratan atau bagiannya ke dalam dua atau lebih wilayah kekuasaan yang berbeda. Perbatasan yang dibentuk oleh sungai menunjukkan bahwa perbatasan seperti ini menjadikan sebuah aliran sungai sebagai pembatas antar wilayah dua negara yang bertetangga. Sedangkan perbatasan berbentuk pegunungan adalah dimana pegunungan yang menjadi perbatasan adalah bagian pegunungan yang tertinggi yang biasa disebut dengan Watershed yang artinya bahwa bagian-bagian tertinggi dari pegunungan itu merupakan pemisah dari semua aliran sungai-sungai yang mengalirkan ke jurusanjurusan yang berlawanan. Untuk perbatasan laut biasanya diatur melalui sebuah konvensi, dimana bila terjadi kegagalan maka dilakukan perundingan bilateral, dan bila ternyata masih terjadi kegagalan maka perselisihan tentang 
hal ini dapat dibawa ke Mahkamah Internasional di Den Haag, Belanda. Dan yang terakhir adalah Perbatasan Udara, dimana ruang udara yang merupakan bagian wilayah negara adalah ruang yang terletak di atas permukaan daratan dan di atas wilayah perairan.

C. Kesejahteraan Masyarakat

Berbicara tentang kesejahteraan, kata ini berasal dari kata Sejahtera, yang menurut Wikipedia berarti tentang hal yang menunjuk ke keadaan yang baik, kondisi manusia dimana orang-orangnya dalam keadaan makmur, dalam keadaan dan damai. (https://id.wikipedia.org/wiki/Kesejahteraan). Sedangkan pengertian Kesejahteraan Masyarakat, jika melihat pengertiannya berdasarkan Undangundang No 11 Tahun 2009, tentang Kesejahteraan Masyarakat, kesejahteraan masyarakat adalah kondisi terpenuhinya kebutuhan material, spiritual, dan sosial warga negara agar dapat hidup layak dan mampu mengembangkan diri, sehingga dapat melaksanakan fungsi sosialnya. Dari Undang-Undang tersebut dapat kita cermati bahwa untuk mengukur tingkat kesejahteraan dapat dinilai dari kemampuan seorang individu atau kelompok dalam usahanya memenuhi kebutuhan material dan spiritualnya. Kebutuhan material dapat kita hubungkan dengan pendapatan yang nanti akan mewujudkan kebutuhan akan pangan, sandang, papan dan kesehatan. Kemudian kebutuhan spiritual kita hubungkan dengan pendidikan, kemudian keamanan dan ketentraman hidup.

Biro Pusat Statistik Indonesia (2015:7) menerangkan bahwa guna melihat tingkat kesejahteraan rumah tangga suatu wilayah ada beberapa indikator yang dapat dijadikan ukuran, antara lain adalah: 1. Tingkat pendapatan keluarga 2 . Komposisi pengeluaran rumah tangga dengan membandingkan pengeluaran untuk pangan dengan non-pangan 3 . Tingkat pendidikan keluarga 4. Tingkat kesehatan keluarga 5. Kondisi perumahan serta fasilitas yang dimiliki dalam rumah tangga.

\section{Metode Penelitian}

Pada penelitian ini penulis menggunakan metode riset kepustakaan, yaitu dengan menggunakan data-data sekunder dari sumber-sumber yang dijadikan objek penelitian, baik buku-buku atau literatur, media elektronik (situs internet), media online, yang ada kaitannya dengan masalah penelitian 
42 | Jurnal Agus Hendrayady. Membangun Perbatasan...

ini. Pengumpulan data dalam penelitian ini dilakukan dengan menggunakan studi kepustakaan.

\section{Pembahasan}

Provinsi Kepulauan Riau sebagai provinsi yang berbasis kepulauan memiliki luas wilayah lautan seluas $241.215 \mathrm{Km}^{2}$ atau $96 \%$ dan daratan seluas $10.595 \mathrm{Km}^{2}$ atau $4 \%$ dengan total wilayah seluas $251.810 \mathrm{Km}^{2}$ dengan topografi yang terdiri dari gugusan pulau yang dipisahkan oleh lautan. Seperti telah dijelaskan diawal tulisan ini bahwa 19 pulau yang dimiliki oleh Provinsi Kepulauan Riau adalah pulau-pulau terdepan. Menurut Hendrayady (2017:509) seluruh pulau terdepan di Provinsi Kepulauan Riau terbilang di bawah garis kemapanan, miskin sarana dan prasarana, kurang akses hingga SDM yang terbatas.

Secara umum masalah mendasar Provinsi Kepulauan Riau adalah minimnya infrastruktur, akses antar pulau, komunikasi dan elektrifikasi. Lebih lanjut, secara spesifik Hendrayady (2017:507), menyatakan bahwa masalahmasalah yang sering terjadi adalah penyelundupan kayu (illegal logging), pertambangan liar, illegal fishing, Human Trafficking, penyelundupan narkoba, penyelundupan barang-barang ilegal seperti sembako, barang elektronik, pakaian bekas yang biasa disebut Roma (Rombengan Malaysia). Mengingat kondisi yang terjadi seperti ini maka sudah seharusnya pemerintah terutama Pemerintah Provinsi Kepulauan Riau harus mampu menjaga dan mengelola wilayah perbatasan sebagai beranda terdepan yang aman, tertib dan maju serta bekerja lebih keras agar dapat mengangkat kesejahteraan masyarakat yang berada di pulau-pulau terdepan tersebut.

Masalah unik lainnya yang dihadapi oleh Pemerintah Provinsi Kepulauan Riau ternyata bukan hanya dari "internal" saja tetapi juga mendapatkan tantangan dari "eksternal" yang berupa "adanya Kemajuan dan kemewahan" dari negara-negara tetangga, Singapura dan Malaysia.

Kemajuan dan kemewahan negara tetangga ini menjadi "daya tarik atau magnet" bagi masyarakat terutama yang tinggal di daerah perbatasan. Fasilitas dan infrastruktur kedua negara tetangga tersebut, terutama fasilitas kesehatan sehingga membuat masyarakat berobat bahkan terkadang berbelanja kesana. Maka tidak ada langkah lain yang bisa dilakukan oleh 
pemerintah terutama pemerintah Provinsi Kepulauan Riau untuk dapat meningkatkan kesejahteraan masyarakat yang tinggal di daerah perbatasan.

Permasalahan-permasalahan yang seringkali terjadi ini membuat Pemerintah Provinsi Kepulauan Riau memasukkan program mengenai masalah perbatasan ini kedalam RPJMD tahun 2016-2021, yaitu :

1. Program Pengembangan Wilayah Perbatasan.

2. Program Pengembangan Pesisir, Laut, dan Pulau-Pulau Kecil.

3. Program Pengembangan, Pengelolaan Pulau-Pulau Kecil Terdepan.

4. Program Peningkatan Kesadaran dan Penegakan Hukum dalam Pendayagunaan Sumber Daya Laut. (Sumber : Bappeda Provinsi Kepulauan Riau).

Berkenaan dengan masalah perbatasan ini telah juga dikembangkan rencana induk pengembangan wilayah perbatasan di Provinsi Kepulauan Riau, yaitu :

1. Memacu peningkatan kesejahteraan dan memberdayakan masyarakat perbatasan yang sinergis dengan perekonomian wilayah negara tetangga dan wilayah lainnya.

2. Meningkatkan efektivitas pembangunan wilayah perbatasan melalui pemberdayaan lembaga ekonomi, sosial dan kemasyarakatan.

3. Mengembangkan SDM sebagai modal penggerak pembangunan wilayah perbatasan.

4. Membuka isolasi dan keterbelakangan wilayah perbatasan (fisik maupun informasi), dengan membangun infrastruktur yang memadai.

5. Mengelola sumberdaya kelautan untuk kesejahteraan masyarakat.

6. Mengembangkan sistem kerjasama pembangunan antar pemerintah dan pemerintah daerah maupun antar pelaku usaha. (Sumber : Bappeda Provinsi Kepulauan Riau).

Strategi yang digunakan untuk mengembangkan daerah perbatasan di Provinsi Kepulauan Riau ini, adalah sebagai berikut :

1. Menjadikan kawasan perbatasan sebagai beranda terdepan.

2. Membangun dengan pendekatan kesejahteraan.

3. Mengembangkan pusat-pusat pertumbuhan ekonomi.

4. Meningkatkan perlindungan sumber daya alam.

5. Meningkatkan kualitas sumber daya manusia (SDM). 
44 | Jurnal Agus Hendrayady. Membangun Perbatasan...

6. Meningkatkan kerjasama pembangunan. (Sumber : Bappeda Provinsi Kepulauan Riau).

Melihat strategi yang telah dibuat tersebut, ini menunjukkan bahwa agar dapat mewujudkan pembangunan sangat membutuhkan koordinasi yang baik antara seluruh instansi terkait baik pemerintah pusat maupun pemerintah daerah. Didalam visi pembangunan kawasan perbatasan seperti yang tertuang dalam Rancangan Undang-Undang Rencana Pembangunan Jangka Panjang Nasional (RPJMN) Tahun 2005 - 2025 menyebutkan bahwa tujuan pembangunan perbatasan adalah untuk "Mewujudkan Pemerataan Pembangunan dan Berkeadilan". Kalimat ini mengandung pemahaman bahwa : Peningkatan pembangunan daerah; Mengurangi kesenjangan sosial secara menyeluruh; keberpihakan kepada masyarakat, kelompok dan wilayah daerah yang masih lemah; menanggulangi kemiskinan secara drastis; Menyediakan akses yang sama bagi masyarakat terhadap berbagai pelayanan sosial serta sarana dan prasarana ekonomi.

Berdasarkan RPJMN tahun 2005 - 2025 tersebut dalam mengimplementasikan kebijakan pembangunan kawasan perbatasan yang diwujudkan dalam sejumlah program sedikit banyak telah mengubah wajah perbatasan terutama di wilayah Provinsi Kepulauan Riau. Menjawab upaya mencari solusi untuk meningkatkan kesejahteraan masyarakat di pulau-pulau terdepan di Provinsi Kepulauan Riau maka ada beberapa upaya-upaya yang dilakukan oleh pemerintah pusat terutama sekali yang dilakukan oleh Pemerintah Provinsi Kepulauan Riau dengan menggunakan pendekatan keamanan dan pendekatan kesejahteraan. Pendekatan keamanan digunakan untuk memelihara batas wilayah kedaulatan NKRI dan pertahanan keamanan negara, dan pendekatan kesejahteraan dilakukan dengan tujuan untuk menciptakan kemakmuran dan kesejahteraan bagi masyarakat di perbatasan secara berkelanjutan, dengan cara melindungi masyarakat dalam memanfaatkan potensi ekonomi yang ada di pulau-pulau terdepan.

Untuk mencapai tujuan peningkatan kesejahteraan masyarakat di perbatasan menurut Caporaso dan Levine (2008:194), maka pemerimtah pusat dan pemerintah Provinsi Kepulauan Riau dapat melakukan peningkatan pertumbuhan ekonomi yang dapat memberikan multi efek terhadap masyarakat di Kepulauan Riau. Namun berdasarkan fakta yang terjadi jika melihat pada data angka pertumbuhan ekonomi Provinsi Kepulauan Riau 
menunjukkan angka yang fluktuatif. Hal ini dapat dilihat pada tabel berikut ini

Tabel 1.

Angka Pertumbuhan Ekonomi Provinsi Kepulauan Riau

Tahun 2018 - Triwulan I Tahun 2019

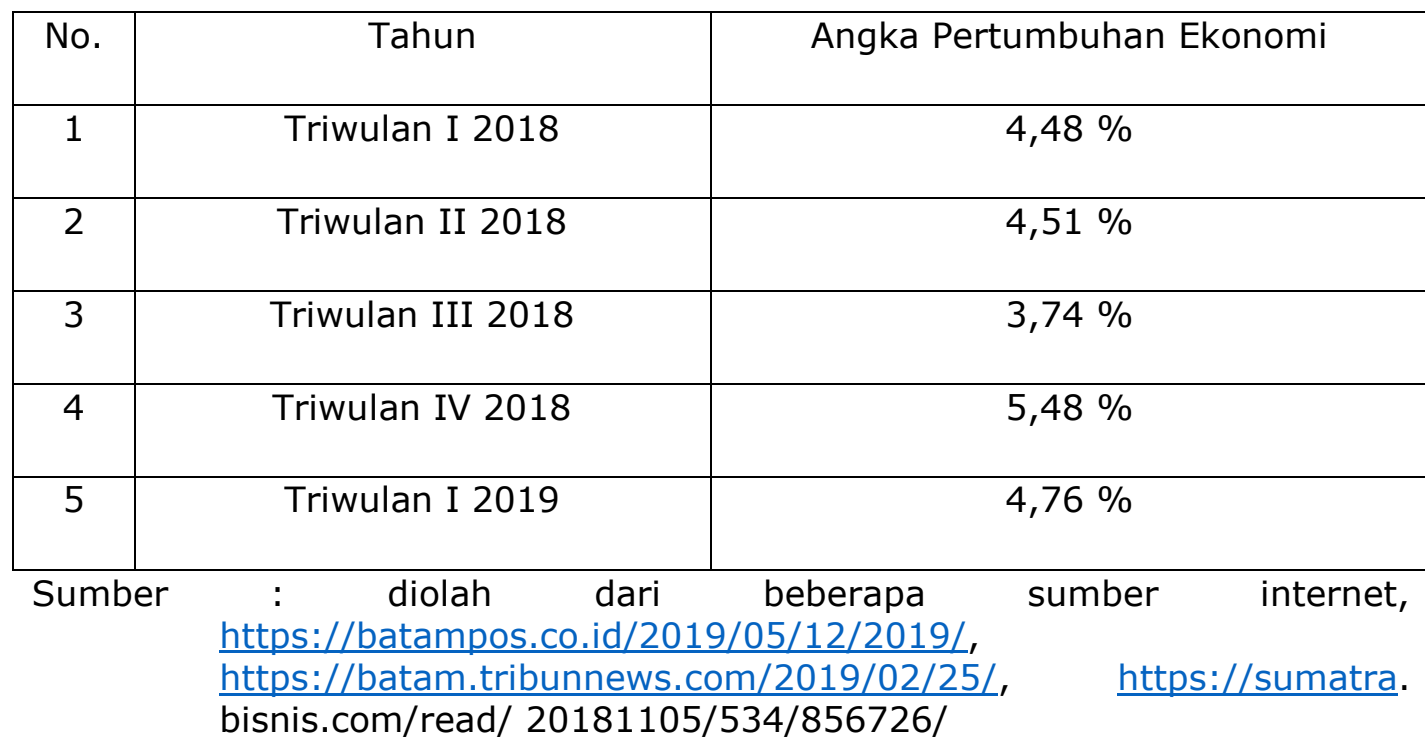

Berdasarkan tabel tersebut dapat dilihat bahwa dengan angka-angka yang fluktuatif tersebut akan berdampak terhadap menurunnya tingkat kesejahteraan masyarakat di daerah. Oleh karena itu Salah satu upaya yang telah dilakukan adalah pada tahun 2017, Pencanangan Program Gerakan Pembangunan Terpadu Kawasan Perbatasan (Gerbangdutas) di Kabupaten Natuna dengan mendapatkan anggaran dana dari pemerintah pusat sebesar Rp. 1,618 Triliun, dengan tujuan untuk mensosialisasikan kebijakan dan program pembangunan wilayah perbatasan negara. Didalamnya juga termasuk peninjauan lapangan atas masalah dan kendala pembangunan daerah, untuk mencari solusinya. (http:www.viva.co.id/berita/bisnis/892215proyek-perbatasan-di-kepulauan-riau-berbiaya-rp1,61-triliun).

Dana tersebut digunakan untuk pembangunan di daerah perbatasan, antara lain percepatan rehabilitasi rumah layak huni, pasar, sekolah, puskesmas, Program Percepatan Pembangunan Desa dan Kelurahan (P3DK), upaya penyelesaian batas negara, serta peningkatan elektrifitas terutama di pulau-pulau kecil dan daerah terpencil melalui Pembangunan Pembangkit Listrik Tenaga Surya (PLTS), Pembangkit Listrik Tenaga Mikro Hidro (PLTMH) 
serta Pengembangan Teknologi Pembangkit Listrik Tenaga Arus Listrik dan pembangunan pelabuhan/dermaga di wilayah perbatasan.

Disisi lain, karena strategisnya wilayah Provinsi Kepulauan Riau ini maka perlu didukung dengan konektivitas yang baik terutama konektivitas laut. Oleh karena itu maka dibangun beberapa pelabuhan dan kapal penyeberangan yang menjadi prioritas sehingga dapat mengurangi kesenjangan intra wilayah dan antar wilayah. (http:www.viva.co.id/berita/bisnis/892215-proyek-perbatasan-di-kepulauanriau-berbiaya-rp1,61-triliun).

Batam sebagai sebuah kota yang juga berbatasan secara langsung dengan negara tetangga Singapura dijadikan andalan pembangunan dan perekonomian sehingga menjadi daerah yang maju, bukan tertinggal seperti daerah lain. Oleh karena itu Batam dijadikan daerah industri, pariwisata, perkapalan, dan jasa. Dan ini sesuai dengan pernyataan dari Triyono Budi Sasongko sebagai Sekretaris BNPP, yaitu : "Pengelolaan potensi maritim harus menjadi prioritas dan perlu kerja yang ekstra, terutama di wilayah perbatasan NKRI yang berbatasan langsung dengan negara tetangga, Malaysia dan Singapura, yakni Kota Batam.". (http://antarakepri.com/berita/24757/batam-manfaatkan-perbatasansebagai-kelebihan).

Bentuk lain yang dilakukan dalam rangka membangun wilayah perbatasan adalah dengan melaksanakan Program Tol Laut. Program Tol Laut dicetuskan oleh Presiden Jokowi bertujuan untuk menghubungkan pelabuhanpelabuhan besar yang ada di Nusantara. Diharapkan dengan adanya hubungan antar pelabuhan-pelabuhan laut, maka akan tercipta kelancaran pengiriman barang hingga daerah-daerah perbatasan. Program Tol Laut dilakukan, terutama untuk daerah Provinsi Kepulauan Riau adalah dikarenakan wilayah Kepulauan Riau banyak laut. Sedangkan dibidang infrastruktur, terutama terkait dengan bidang infrastruktur, maka Pemprov Kepri dan PT. PLN Wilayah Riau dan Kepulauan Riau menghadapi banyak kendala, terutama untuk daerah perbatasan yang banyak gangguan dan kendala, terutama karena kondisi Kepulauan Riau adalah lautan, disamping faktor cuaca dan iklim yang seringkali tidak menentu dan tidak adanya fasilitas bongkar muat pelabuhan. 
Melihat secara keseluruhan dari kebijakan pembangunan kawasan perbatasan yang telah dilakukan oleh pemerintah pusat maupun pemerintah Provinsi Kepulauan Riau memang telah berorientasi pada pemenuhan kepentingan masyarakat, yang artinya pemerintah telah berupaya untuk menerapkan paradigma People Centered Development, yang meletakkan manusia sebagai pusat pertumbuhan. Adapun logika yang mendominasi Paradigma people centered development ini adalah keseimbangan ekologi manusia, dengan didukung sumber pembangunan utamanya adalah informasi dan prakarsa yang kreatif yang tak akan pernah habis, dengan tujuan utamanya adalah perkembangan manusia dengan aktualisasi yang optimal dari potensi manusia. Paradigma ini memberi tempat yang penting bagi prakarsa dan keanekaragaman lokal, dan menekankan pentingnya masyarakat lokal yang mandiri. (Korten dalam Tjokrowinoto, 1999:217). Kemudian manajemen pembangunannya mengubah peranan birokrasi pemerintah dari merencanakan dan melaksanakan pembangunan untuk rakyat, berubah menjadi aktor dalam menciptakan kondisi yang menimbulkan kemandirian rakyat atau dengan kata lain, sebagai katalis dalam mempercepat proses pembangunan yang berpusat kepada kemandirian lokal. (Korten dalam Tjokrowinoto, 1999:214). Pembangunan yang berorientasi dengan menempatkan rakyat sebagai aktor utama, yang memiliki kekuatan di dalam merencanakan, merumuskan dan melaksanakan pembangunan sesuai dengan kemampuan dan potensi yang dimilikinya, dalam mewujudkan keterkaitan (interlinkages) yang tepat antara alam, aspek sosio-ekonomis dan kultur dengan melihat saat ini dan di masa datang

\section{Kesimpulan dan Saran}

Berdasarkan uraian pada pembahasan penelitian ini, maka dapat penulis simpulkan bahwa :

1. Pembangunan wilayah perbatasan sebagai beranda terdepan negeri ini bukan hanya tugas pemerintah pusat saja, tetapi juga tugas pemerintah daerah dengan didukung oleh masyarakat sehingga tujuan mewujudkan kesejahteraan masyarakat dapat tercapai.

2. Upaya-upaya membangun daerah perbatasan Provinsi Kepulauan Riau telah dituangkan di dalam RPJMD Provinsi Kepulauan Riau tahun 20162021, yang diikuti dengan rencana induk pengembangan wilayah 
48 | Jurnal Agus Hendrayady. Membangun Perbatasan...

perbatasan di Provinsi Kepulauan Riau, disertai dengan strategi untuk pengembangan wilayah perbatasan di Provinsi Kepulauan Riau.

3. Bentuk-bentuk pembangunan di wilayah perbatasan Provinsi Kepulauan Riau terus dilakukan, seperti melakukan rehabilitasi bagi rumah agar layak huni, perbaikan sarana pasar, sekolah dan puskesmas, serta program percepatan pembangunan bagi desa dan kelurahan, penyelesaian batas negara (karena merupakan batas laut), serta mengaliri pulau-pulau kecil dan terpencil dengan listrik, serta menghubungkan antar pulau dengan Program Tol laut.

Adapun saran dari penelitian ini adalah sebagai berikut :

1. Agar pemerintah pusat maupun pemerintah daerah Provinsi Kepulauan Riau dan Kabupaten dan Kota selalu memperhatikan daerah perbatasan dan membangun daerah perbatasan dengan menyediakan anggaran yang memadai.

2. Semangat membangun daerah perbatasan sebagai beranda terdepan negara bukan hanya wacana atau nilai jual politik saja tetapi harus diaplikasikan sehingga keterwujudan adalah hal yang niscaya.

3. Sumber daya manusia di daerah perbatasan juga perlu dimaksimalkan sehingga mereka dapat ikut serta dalam membangun daerah mereka sendiri tanpa harus mengandalkan pemerintah saja, sehingga Good Governance dapat terwujud.

\section{DAFTAR PUSTAKA}

\section{Buku-Buku}

Caporaso, J.A, dan D.V. Levine, 2008, Teori-Teori Ekonomi Politik, Pustaka Pelajar, Yogyakarta.

Nurmandi, Achmad, dkk, 2012, Menjaga Indonesia dari Kepri : Peluang, Tantangan dan Profil 19 Pulau Terdepan Indonesia di Kepulauan Riau, Badan Pengelola Perbatasan Provinsi Kepri, Tanjungpinang.

Siagian, Sondang P., 2005, Administrasi Pembangunan : Konsep, Dimensi, dan Strateginya, Bumi Aksara, Jakarta.

Tjokrowinoto Moeljarto, 1999, Pembangunan, Dilema dan Tantangan, Pustaka Pelajar, Yogyakarta.

\section{Jurnal}

Hendrayady, Agus, "Membangun Wilayah Perbatasan Provinsi Kepulauan Riau (Suatu Kajian Terhadap Pemerataan Pembangunan Indonesia sebagai 
Negara Maritim)", Prosiding Seminar Nasional : Strategi Pembangunan Daerah Kepulauan, FISIP Umrah, 2017, ISBN. 978-602-50727-0-3

Hendrayady, Agus, "Strategi Pembangunan Wilayah Perbatasan Provinsi Kepulauan Riau", JUAN : Jurnal Ilmu Administrasi Negara, Juni 2018: Volume 6, Nomor 1.

\section{Data Internet}

Bappeda.kepriprov.go.id/..../121-arah-kebijakan-rencana-kerjapembangunan-tahun-2017. Diakses pada hari sabtu, 28 Oktober 2017, pukul $13.45 \mathrm{Wib}$.

http://antarakepri.com/berita/24757/batam-manfaatkan-perbatasan-sebagaikelebihan. Diakses pada hari Minggu, 29 Oktober 2017, pukul 22.42 Wib.

http:www.viva.co.id/berita/bisnis/892215-proyek-perbatasan-di-kepulauanriau-berbiaya-rp1,61-triliun. Diakses pada hari Minggu, 29 Oktober 2017, pukul $18.08 \mathrm{Wib}$.

https://batampos.co.id/2019/05/12/ekonomi-kepri-turun-pada-awal-2019/. Diakses pada hari Jum'at, 5 juni 2019, pukul $10.30 \mathrm{Wib}$

https://batamtoday.com/home/read/78242/Daerah-Perbatasan-Kepri-ButuhInfrastruktur-dan-Kesejahteraan. Diakses pada hari Sabtu, 28 Oktober 2017, pukul 13.50 Wib.

https://batam.tribunnews.com/2019/02/25/pertumbuhan-ekonoi-kepri-2019diproyeksikan-52-56-persen-ini-sektor-yang-meningkat?page-2. Diakses pada hari Jum'at, 5 juni 2019, pukul 10.26 Wib

https://id.wikipedia.org/wiki/Kesejahteraan. Diakses pada hari Jum'at, 5 Juni 2019, pukul 10.15 Wib.

https://sumatra.bisnis.com/read/20181105/534/856726/ekonomi-keprimelambat-cuma-tumbuh-374. Diakses pada hari Jum'at, 5 juni 2019, pukul $10.50 \mathrm{Wib}$.

Sari, Veni Ayu Kartika, Pengembangan Kawasan Perbatasan Berbasis Spasial. Dari https://indonesiadevelopmentforum.com/2018/idea/1757pengembangan-kawasan-perbatasan-berbasis-spasial. Diakses pada hari Kamis, 02 Mei 2019, pukul 19.20 Wib.

\section{Dokumen}

Undang-Undang No. 11 Tahun 2009 tentang Kesejahteraan Masyarakat. Biro Pusat Statistik, Indikator Kesejahteraan Rakyat Tahun 2015. RPJMD Provinsi Kepulauan Riau Tahun 2016 - 2021. 